\title{
Análise da soroprevalência do herpesvírus bovino tipo-1 e do cortisol sérico em diferentes situações de manejo no Rio Grande do Sul*
}

\author{
MARCELO MARONNA DIAS
}

Paulo Michel Roehe (Orientador - UFRGS)

Banca: Dr. Diogo Onofre Gomes de Souza (UFRGS), Dr. David Driemeier (UFRGS), Carlos Octávio Cordovés Céspedes (IRFA-RS)

\begin{abstract}
Em quatro artigos estudou-se as variações de cortisol sérico frente a diferentes situações de manejo, a soroprevalência e dinâmica do BHV-1 e taxas de prenhez e abortos em gado de corte. No primeiro, foram avaliados os níveis de cortisol sérico frente a situações de manejo. Os níveis de cortisol sérico nas terneiras de 80 dias de idade $(0,22 \pm 0,25 \mathrm{ug} / \mathrm{dl}) \mathrm{diferiram}$ significativamente de todas as categorias ( $\mathrm{P}<0,001)$, com exceção das terneiras de 180 dias $(\mathrm{P}=0,81)$. As terneiras com 180 dias $(0,91 \pm 0,43 \mathrm{ug} / \mathrm{dl})$ não diferiram das novilhas de um ano e dois anos $(1,97 \pm 1,40 \mathrm{ug} / \mathrm{dl} \mathrm{e} 2,15 \pm 1,41 \mathrm{ug} / \mathrm{dl}$, respectivamente), mas diferiram das vacas. As novilhas nas duas idades não diferiram das vacas de três até oito anos de idade (3,25 $\pm 1,89 \mathrm{ug} / \mathrm{dl}$; $2,62 \pm 1,27 \mathrm{ug} / \mathrm{dl} ; 2,42 \pm 0,93 \mathrm{ug} / \mathrm{dl} ; 3,12 \pm 0,69 \mathrm{ug} / \mathrm{dl} ; 2,89 \pm 0,41 \mathrm{ug} / \mathrm{dl} ; 2,12 \pm 1,22 \mathrm{ug} / \mathrm{dl}$, respectivamente). Os touros de um ano $(1,00 \pm 0,73 \mathrm{ug} / \mathrm{dl})$, de dois anos $(0,89 \pm 0,43 \mathrm{ug} / \mathrm{dl})$ e três anos $(1,44 \pm 0,60 \mathrm{ug} / \mathrm{dl})$ diferiram estatisticamente das terneiras de 80 dias de idade e das vacas. Frente a uma situação evidente de estresse (castração), o cortisol sérico variou cinco vezes, indo de $0,66 \mathrm{ug} / \mathrm{dl}$ para 3,36 ug/dl. Estes resultados indicam que há uma variação de cortisol sérico, com a idade, em bovinos de corte, e que este hormônio pode elevar-se diante de uma situação de estresse. O artigo 2 determinou o cortisol em terneiras e examinou as variações em função do tipo de desmame (precoce e tradicional). As coletas foram feitas $24,48,72$ e 168 horas pós-desmame. Os animais foram pesados para avaliar o ganho de peso nos dois grupos. Os valores de cortisol sérico no grupo precoce elevaram-se de $0,22 \pm 0,25 \mathrm{ug} / \mathrm{dl}$, em níveis basais antes do desmame, para 0,71 $\pm 0,64 \mathrm{ug} / \mathrm{dl}$ nas 24 horas pósdesmame, baixando para $0,26 \pm 0,30 \mathrm{ug} / \mathrm{dl}$ em uma semana. No grupo tradicional elevaram-se de $0,91 \pm 0,43 \mathrm{ug} / \mathrm{dl}$, em níveis basais antes do desmame para 1,94 $\pm 0,89 \mathrm{ug} / \mathrm{dl}$ nas 24 horas, baixando para $0,99 \pm 0,46 \mathrm{ug} / \mathrm{dl}$ em uma semana. O trabalho mostrou que: houve elevação nos níveis séricos de cortisol nas primeiras 24 horas pós-desmame, o grupo desmamado tradicionalmente teve um ganho de peso significativamente superior $(\mathrm{P}<0,001)$ ao grupo desmamado precocemente; no desempenho reprodutivo não houve diferenças significativas nas taxas de prenhez e de perdas. No terceiro artigo foi estimada por soroneutralização a soroprevalência de anticorpos contra o BHV-1 em animais não vacinados e determinou-se a chance de apresentarem a infecção, em diversas categorias animais. Em todas as categorias ocorreram animais soropositivos.Cabe salientar que, após o primeiro serviço, nas novilhas de dois anos, a soroprevalência para o BHV-1 aumentou dez vezes, indo de $3,85 \%$ para $38,5 \%$. A soroprevalência aumenta, conforme a idade, de forma significativa $(\mathrm{P}<0,001)$ após o período reprodutivo. No quarto artigo foram avaliadas as taxas de prenhez e de perdas, até o parto, em propriedades rurais que utilizam, ou não, uma vacina que protege para doenças reprodutivas. Acompanhou-se 27.774 vacas (13.477 vacinadas e 14.297 não vacinadas), por quatro temporadas reprodutivas, com IA e repasse com touros. O índice geral de prenhez das vacas vacinadas foi de 72,7\% e, das vacas não vacinadas, foi de 70,4\%. Essa diferença, considerando as 27.774 , foi estatisticamente significativa $(\mathrm{P}<0,001)$. A taxa de perdas (abortos) das vacas vacinadas foi de 2,38\% e, das vacas não vacinadas, de 2,98\%. Essa diferença, considerando um total de 19.865 vacas prenhas, foi estatisticamente significativa $(\mathrm{P}=0,004)$.
\end{abstract}

Descritores: IBR, BHV-1, desmame precoce, estresse, cortisol sérico.

Apresentada: 21 fevereiro 2006

*Tese de Doutorado n.64 (Especialidade: Virologia). 84f. Programa de Pós-graduação em Ciências Veterinárias[www.ufrgs.br/ppgcv], Faculdade de Veterinária, Universidade Federal do Rio Grande do Sul (UFRGS), Porto Alegre/RS. CORRESPONDÊNCIA: M.M. Dias [mmaronna@terra.com.br]. 


\title{
Analysis of serum prevalence of bovine herpesvirus type 1 and seric cortisol in different situations of manegement in Rio Grande do Sul state**
}

\author{
MARCELO MARONNA DIAS
}

\author{
Paulo Michel Roehe (Adviser - UFRGS)
}

Committee: Dr. Diogo Onofre Gomes de Souza (UFRGS), Dr. David Driemeier (UFRGS), Carlos Octávio Cordovés Céspedes (IRFA-RS)

Four articles studied evaluated levels of serum cortisol under stressful situations, seroprevalence and dynamics of BHV-1, pregnancy and abortion rates in beef cattle.

The first study evaluated levels of serum cortisol in animals submitted to stressful conditions. Serum cortisol levels were evaluated in 80 and 180 days calves, 1 and two year old heifers, cows ranging from 3 to 8 years, and in bulls of 1,2 and 3 years, as well as in 3 year males submitted to castration. Calves with 80 days of age $(22 \mu \mathrm{g} / \mathrm{dl} \pm 0,25 \mu / \mathrm{dl})$ had serum levels statistic different ( $\mathrm{p}<0,001)$ from all the other categories, except for 180 days calves $(\mathrm{P}=0,81) ; 180$ days calves $(0,91 \pm 0,43 \mathrm{ug} / \mathrm{dl}) \mathrm{did}$ not differ from the one and two year heifers $(1,97 \pm 1,40 \mathrm{ug} / \mathrm{dl}$ and $2,15 \pm 1,41 \mathrm{ug} / \mathrm{dl}$, respectively), but had levels statistically different from all the other cows. Heifers in both ages did not differ from cows from 3 to 8 years ( $3,25 \pm 1,89 \mathrm{ug} / \mathrm{dl} ; 2,62 \pm 1,27 \mathrm{ug} / \mathrm{dl}$; $2,42 \pm 0,93 \mathrm{ug} / \mathrm{dl} ; 3,12 \pm 0,69 \mathrm{ug} / \mathrm{dl} ; 2,89 \pm 0,41 \mathrm{ug} / \mathrm{dl} ; 2,12 \pm 1,22 \mathrm{ug} / \mathrm{dl}$, respectivelly). The bulls at one (1,00 $\pm 0,73 \mathrm{ug} / \mathrm{dl})$, two $(0,89 \pm 0,43 \mathrm{ug} / \mathrm{dl})$, and three years old $(1,44 \mu \mathrm{g} / \mathrm{dl} \pm 0,60 \mathrm{ug} / \mathrm{dl})$ had levels statistically different from the 80 days calves and cows. In a stressful situation, serum cortisol enhanced five times, ranging from $0,66 \mu \mathrm{g} / \mathrm{dl}$ to $3,36 \mu \mathrm{g} / \mathrm{dl}$. These results suggest that serum cortisol changes with age, and that this hormone may be useful to demonstrate an stressful situation in beef cattle. The second study aimed to determine physiologic values for serum cortisol in calves and to examine whether different weaning schedules would have any effect on such values. To evaluate serum cortisol levels after weaning, blood samples were collected at 24, 48, 72 and 168 hours after weaning. Average daily gain at measures in both groups. Pregnancy rate and losses until parturition were the parameters used to evaluate reproductive performance. Data showed that basal serum cortisol $(0,22 \pm 0,25 \mathrm{ug} / \mathrm{dl})$ in the early weaning group enhanced to $0,71 \pm 0,64 \mathrm{ug} / \mathrm{dl}$ in the first 24 hours after weaning, reducing to $0,26 \pm 0,30 \mathrm{ug} / \mathrm{dl}$ after a week. In the traditional weaning group, basal leves $(0,91 \pm 0,43 \mathrm{ug} / \mathrm{dl})$ enhanced to $1,94 \pm 0,89 \mathrm{ug} / \mathrm{dl}$ in the first 24 hours, and reduced to $0,99 \pm 0,46 \mathrm{ug} / \mathrm{dl}$ in a week. This study showed that serum cortisol levels enhanced in the first 24 hours after weaning for both groups, returning to basal levels in a week. The traditional weaning group had higher average daily gain $(\mathrm{P}<0,001)$. No significant differences were observed for pregnancy rates and losses until parturition.

The third study had the objective of estimating antibody presence against BHV-1, by seroneutralization in non vaccinated animals, and evaluate the chance of animal developing infection in several categories. Antibody presence in the herd was in all categories. Antibody prevalence inhanced 10 times after first service in the $2 \mathrm{yr}$ heifers, turning from 3,85\% to $38,5 \%$. Antibody presence enhances with age $(\mathrm{P}<0,001)$, specially after two years old, and chances of developing infection is higher after breeding season. The fourth study was conducted to evaluate pregnancy rates and losses until parturition (abortion) in farms, that either use a reproductive vaccine or not. A total of 27774 cows were analysed, with 13477 cows routinely vaccinated and the other 14297 cows not vaccinated, for four breeding seasons. The cows were bred AI and exposed to a fertile bull. Total pregnancy rate was $72,7 \%$ in the group of vaccinated cows and $70,4 \%$ in the non vaccinated. This diference, considering the total 27774 cows was statiscally significant ( $<<0,001$ ). Abortion rate was $2,38 \%$ in the vaccinated vs $2,98 \%$ in the non vaccinated group, and was statistically different $(p=0,004)$. These results indicate that vaccinated herds had higher pregnancy rates and less losses by abortion.

Key words: IBR, BHV-1, early weaning, stress, seric cortisol. 